\title{
Enhanced Bioavailability and Anticancer Activity of Vitamin Analogs
}

\section{Kakullamarri PR* and Rao KLN}

Research and Development, Ascent Pharmaceuticals, Central Islip, NY, USA

\begin{abstract}
There is increased evidence to show that dietary supplementation of vitamins contributes to cancer prevention and also therapy. This paper explains the anticancer activity of few vitamins and the necessity of preparing their analogs to enhance their bioavailability. While the vitamin supplementation is needed in various health disorders, over supplementation of the same may not be effective due to failure to reach over maximal concentrations in the body. Vitamin mediated anticancer activities include cell cycle progression inhibition, targeting cell survival, inducing autophagy or apoptosis, inhibiting hypoxia, eradication of oxygen free radicals and immune modulation. As the in vitro data seems sufficient to support vitamin biological effects, advanced research is needed to support their in vivo activity and long-term treatment.
\end{abstract}

Keywords: Vitamin; Bioavailability; Tocotrienols; Cancer

\section{Introduction}

Being lipophilic, tocotrienol sub group of Vitamin E compounds face difficulties in reaching optimum concentration in blood and further at target site $[1,2]$. This is because of poor water solubility that is limiting their absorption via gut. Further, they are metabolized rapidly resulting in excretion in urine $[3,4]$. In order to enhance their bioavailability and natural limitations, they were subjected to synthesis of derivatives [5-7].

The active form of vitamin D3, 1, 25-dihydroxy vitamin D3 has many functional roles including cell growth regulation, differentiation, proliferation, apoptosis and immune responses [8-10]. But, it can be given directly to the patient due to problems arising of hypercalcaemic side-effects at pharmacological doses [11,12]. This leads to calcium deposition in various organs. Hence analogs were prepared for vitamin D3 that has minimal side effects. These analogs can be used in cancer and other inflammatory diseases [13-15].

Vitamin $\mathrm{K}$ is also known for its anticancer activity [16]. Initially it was known for its nutritional activities that mediate clotting mechanisms in human beings $[17,18]$. However, vitamin K1, K2 and K3 were shown anticancer potential [19]. Research evidence is available to show the anticancer activity of vitamin $\mathrm{K}$ mediated by acting on tyrosine kinases and phosphatases, modulating various transcription factors such as Myc and Fos [16].

As the natural compounds have difficulty in achieving pharmacological concentrations in blood, numerous nano formulations, sustained release dosage forms, targeting delivery and other approaches need to be used. They have been shown significant efficiency in cancer and also in other forms of diseases [20-25]. Formulation type can alter their biological activity in favor of cancer treatment [26-29].

\section{Intake of Vitamins and Cancer Risk}

Early research is available, where scientists studied the correlation between intake of vitamins in diet and women breast cancer risk [30]. The analysis was conducted in a total of 121, 700 women in multiple regions. The study participants were provided with a questionnaire. In that they have to answer questions regarding their menopausal status, suspected risk of cancer and cardiovascular diseases, parity and any known risk factors regarding cancer or other diseases. They were also asked about their diet to estimate the impact of dietary constituents in cancer occurrence. The diet was calculated to measure their vitamin content, apart from calculating any multivitamin supplements they have been taking. Vitamin A intake had inverse relation with the breast cancer incidence. At the same time, there was no inverse relation between vitamin $\mathrm{C}$ and $\mathrm{E}$ to the breast cancer incidence. This can be because of failure to reach therapeutic levels in the body. Moreover, when the dietary vitamin A levels are sufficient enough, the separate supplementation of the same does not have any significant effect on breast cancer risk [30,31].

\section{Vitamin D Analogs}

Toovercome the limitations associated with vitamin $\mathrm{D}\left(1,25(\mathrm{OH}) 2 \mathrm{D}_{3}\right)$ mediated in vivo anticancer activity, the analogs of vitamin $\mathrm{D}$ were tested for their anti-proliferative activity [32]. In vitro metabolic activity was calculated for the vitamin $\mathrm{D}$ analogs by incubating them with microsomal proteins. Liver microsomes from different species such as human, mouse, rat, dog and monkey were used in the study to see the variations of activity. Results indicated that $20 \mathrm{~S}(\mathrm{OH}) \mathrm{D}_{3}$ and $20 \mathrm{R}(\mathrm{OH}) \mathrm{D}_{3}$ both have good metabolic stability irrespective of variations between them against multi species microsomes. The half-life for $20 \mathrm{~S}(\mathrm{OH}) \mathrm{D}_{3}$ was $50 \mathrm{~min}$, and $20 \mathrm{R}(\mathrm{OH}) \mathrm{D}_{3}$ was just $30 \mathrm{~min}$. When compared with in the species, the human microsomes were favorable in terms of half-life with a value of 30-60 min. As the main purpose of the study is to lower the in vivo toxicity of hypercalcemia, mice studies were conducted. The two analogs were given to mice in intra peritoneal route for three weeks ant fixed doses. Following, blood chemistry and pathological analysis were conducted in them. Organs were separated after the conclusions of experiment and fixed on slides for analysis. Even at high dose of $60 \mu \mathrm{g} / \mathrm{kg}$, the analogs of vitamin D did not exert any hypercalcemia unlike their parent compounds which are known for their hypercalcemic affects [32]. At the same time, the mice lost body weight in parent compound treated group but not in the analogs treated group and control group confirming the safety of the analogs in vivo.

${ }^{*}$ Corresponding author: Kakullamarri PR, Research and Development Ascent Pharmaceuticals, Central Islip, NY, USA, Tel: 631-851-0550; E-mail: praneeth237@gmail.com

Received April 24, 2017; Accepted June 01, 2017; Published June 12, 2017

Citation: Kakullamarri PR, Rao KLN (2017) Enhanced Bioavailability and Anticancer Activity of Vitamin Analogs. J Bioequiv Availab 9: 439-441. doi: 10.4172/jbb. 1000340

Copyright: (C) 2017 Kakullamarri PR, et al. This is an open-access article distributed under the terms of the Creative Commons Attribution License, which permits unrestricted use, distribution, and reproduction in any medium, provided the original author and source are credited. 
Citation: Kakullamarri PR, Rao KLN (2017) Enhanced Bioavailability and Anticancer Activity of Vitamin Analogs. J Bioequiv Availab 9: 439-441. doi: $10.4172 / \mathrm{jbb} .1000340$

Liver injury or damage markers including alanine aminotransferase, alkaline phosphatase, aspartate aminotransferase, and cholesterol were tested revealing no analogs treatment associated unwanted toxic effects. Histological analysis indicated no calcification in analogs treated group of mice organs including liver, heart and kidney. Other than toxicity studies, anti-proliferative studies showed similar or higher effect of analogs compared to their parent compounds. Analogs, $20 \mathrm{~S}(\mathrm{OH}) \mathrm{D}_{3}$ and $20 \mathrm{R}(\mathrm{OH}) \mathrm{D}_{3}$, also translocated the vitamin $\mathrm{D}$ receptor (VDR) to the nucleus from cytoplasm which can be effective to make gene regulation mediated anti-proliferative activity [32].

\section{Oxazine Derivatives of Tocotrienols}

While parent compounds g- and d-Tocotrienols do not have significant in vivo anticancer activity in mouse model of mammary tumor, their oxazine derivatives were shown promising results [26]. Subjecting the chromane ring of parent tocotrienols to the electrophilic substitution reactions, namely, Mannich and LedererManasse procedures resulted in 42 new products. These included the 3,4-dihydro-1,3-oxazines 3-29 and 35-44, Mannich bases 30-31, and the hydroxymethyl analogs 32-34 [33].

After the oxazine derivatives of $\mathrm{g}$ - and $\mathrm{d}$ - tocotrienols were prepared, they were tested on $+\mathrm{SA}$ cell lines. These are estrogen receptor independent mammary tumor cell lines that were derived from spontaneous adenocarcinoma of $\mathrm{BALB} / \mathrm{c}$ mice [34]. The cells were treated with oxazine derivatives, compound $26,31,39,40$ and 44 , for 4 days period to measure cell viability and estimate further anticancer activity. From the results, it is clear that IC50 values of the oxazine derivatives was similar or lower to that of their respective parent compounds [33]. Ensuring the in vitro anticancer activity led to the formulation of nanoemulsions with them. Nano emulsions were prepared by various concentrations of phospholipids and hydrophilic surfactants. Aqueous and lipophilic phase were prepared separately and passed through homogenizer to get the emulsions. They were tested for droplet size and size distribution using zeta potential, and microscopic studies. Parent compounds were also subjected to nanoemulsions preparation along with the oxazine derivatives. Following, mammary tumor was developed in the mice and started the treatment with nanoemulsions. Even the IC50 values for in vitro treatment were similar to their parent compounds, all the oxazine derivatives showed significant tumor growth delay compared to their parent compounds in 11-day treatment period. Tumors were isolated at the end and protein analysis revealed that, $\mathrm{g}$ - and d-tocotrienols mediated decrease in tumor growth was due to lowering of cell cycle regulatory proteins cyclin D1, CDK2, CDK4 and CDK6 [33]. However, this decrease was not very significant compared to the a-tocopherol containing nanoemulsions. At the same time, oxazine derivative containing nanoemulsions resulted in significant decrease in the cell cycle progression proteins. Moreover, their anticancer activity was mediated by decreased phosphorylation of cell survival protein Akt and inflammatory mediator, NFkB. Moreover, compound 44 that is derivative of d-tocotrienol showed antihypoxic activity in vitro and in vivo [35].

\section{Conclusion}

\section{Natural compounds in colon cancer migration}

In a recent study, a total of 75 compounds including alkaloids, phenylpropanoids, flavonoids, steroids and terpenoids were tested for their anticancer activity against 26-L5 cells that are murine adenocarcinoma cell line having high liver metastatic potential [36]. Tumor metastasis leads to the death of patient due to poor response to the treatment. Metastasis greatly changes the genotype of the cancer cells due to multiple mutations leading to more aggressive form [37-41]. It is not easy to track the metastatic cells during the process and further making it difficult to target. However, 23 of the 75 compounds that were tested in this research showed potent anti-migratory activity against the highly metastatic colon cancer cells. Five compounds, evodiamine, corydaline, papaverine, magnolol, and kaempferol, had lower IC50 values in inhibiting the migration but had higher IC50 in regard to the proliferation inhibition. Evodiamine was the most potent with IC50 of $1.25 \mathrm{ug} / \mathrm{mL}$. When compared with the standard chemotherapy drug, Paclitaxel, Evodiamine also showed dose dependent effect on migration inhibition [36].

\section{References}

1. Kang MJ, Cho JY, Shim BH, Kim DK, Lee J (2009) Bioavailability enhancing activities of natural compounds from medicinal plants. J Med Plants Res 3: 1204-1211

2. Walle T (2011) Bioavailability of resveratrol. Ann N Y Acad Sci 1215: 9-15.

3. Abuasal B, Sylvester PW, Kaddoumi A (2010) Intestinal absorption of gammatocotrienol is mediated by Niemann-Pick $\mathrm{C} 1$-like 1: in situ rat intestinal perfusion studies. Drug Metab Dispos 38: 939-945.

4. Wu JH, Croft KD (2007) Vitamin E metabolism. Mol Aspects Med 28: 437-452.

5. Behery FA, Akl MR, Ananthula S, Parajuli P, Sylvester PW, et al. (2013) Optimization of tocotrienols as antiproliferative and antimigratory leads. Eur J Med Chem 59: 329-341.

6. Ananthula S (2014) Mechanisms mediating tocotrienol derivative in vitro and in vivo anticancer effects and inhibition of compensatory responses to hypoxia in the highly malignant mouse+ SA mammary cancer cells. University of Louisiana at Monroe, USA.

7. Sylvester PW, Malaviya A, Ananthula S, Tiwari R (2012) Statins as Anticancer Agents. Statins: Pharmacology, Clinical Implications and Adverse Effects. In: La Grua BMolinelli A (ed.) Nova Science Publishers, USA pp:125-150.

8. Holick MF, Binkley NC, Bischoff-Ferrari HA, Gordon CM, Hanley DA, et al. (2011) Evaluation, treatment, and prevention of vitamin D deficiency: an Endocrine Society clinical practice guideline. J Clin Endocrinol Metab 96: 1911-1930.

9. Wang TJ, Pencina MJ, Booth SL, Jacques PF, Ingelsson E, et al. (2008) Vitamin D deficiency and risk of cardiovascular disease. Circulation 117: 503-511.

10. Lappe JM, Travers-Gustafson D, Davies KM, Recker RR, Heaney RP (2007) Vitamin $D$ and calcium supplementation reduces cancer risk: results of a randomized trial. Am J Clin Nutr 85: 1586-1591.

11. Barbour GL, Coburn JW, Slatopolsky E, Norman AW, Horst RL (1981) Hypercalcemia in an anephric patient with sarcoidosis: evidence for extrarenal generation of 1,25-dihydroxyvitamin D. N Engl J Med 305: 440-443.

12. Abe J, Morikawa M, Miyamoto K, Kaiho S, Fukushima M, et al. (1987) Synthetic analogues of vitamin D3 with an oxygen atom in the side chain skeleton A trial of the development of vitamin $D$ compounds which exhibit potent differentiationinducing activity without inducing hypercalcemia. FEBS Lett 226: 58-62.

13. Jones G (2012) Vitamin D analogs. Rheum Dis Clin North Am 38: 207-232.

14. Tentori F, Hunt WC, Stidley CA, Rohrscheib MR, Bedrick EJ, et al. (2006) Mortality risk among hemodialysis patients receiving different vitamin $\mathrm{D}$ analogs. Kidney Int 70: 1858-1865.

15. Adelli GR, Balguri SP, Majumdar S (2015) Effect of Cyclodextrins on Morphology and Barrier Characteristics of Isolated Rabbit Corneas. AAPS PharmSciTech 16: $1220-1226$

16. Lamson DW, Plaza SM (2003) The anticancer effects of vitamin K. Altern Med Rev 8: 303-318.

17. Price PA, Williamson MK (1981) Effects of warfarin on bone. Studies on the vitamin K-dependent protein of rat bone. J Biol Chem 256: 12754-12759.

18. Knapen MH, Jie KS, Hamulyák K, Vermeer C (1993) Vitamin K-induced changes in markers for osteoblast activity and urinary calcium loss. Calcif Tissue Int 53: 81-85.

19. Okayasu H, Ishihara M, Satoh K, Sakagami H (2001) Cytotoxic activity of 
Citation: Kakullamarri PR, Rao KLN (2017) Enhanced Bioavailability and Anticancer Activity of Vitamin Analogs. J Bioequiv Availab 9: 439-441. doi: $10.4172 / \mathrm{jbb} .1000340$

vitamins K1, K2 and K3 against human oral tumor cell lines. Anticancer Res 21: $2387-2392$

20. Janagam DR, Wang L, Ananthula S, Johnson JR, Lowe TL (2016) An accelerated release study to evaluate long-acting contraceptive levonorgestrelcontaining in situ forming depot systems. Pharmaceutics 8: 28.

21. Balguri SP, Adelli GR, Majumdar S (2016) Topical ophthalmic lipid nanoparticle formulations (SLN, NLC) of indomethacin for delivery to the posterior segment ocular tissues. Eur J Pharm Biopharm 109: 224-235.

22. Balguri SP, Adelli G, Bhagav P, Repka MA, Majumdar S (2015) Development of nano structured lipid carriers of ciprofloxacin for ocular delivery: Characterization, in vivo distribution and effect of PEGylation. Invest Ophthalmol Visual Sci 56: 2269-2269.

23. Ananthula S, Janagam DR, Jamalapuram S, Johnson JR, Mandrell TD, et al. (2015) Development and validation of sensitive LC/MS/MS method for quantitative bioanalysis of levonorgestrel in rat plasma and application to pharmacokinetics study. J Chromatogr B Analyt Technol Biomed Life Sci 1003: 47-53.

24. Adelli GR, Balguri SP, Punyamurthula N, Bhagav P, Majumdar S (2014) Development and evaluation of prolonged release topical indomethacin formulations for ocular inflammation. Invest Ophthalmol Visual Sci 55: 463-463.

25. Adelli GR, Hingorani T, Punyamurthula N, Balguri SP, Majumdar S (2015) Evaluation of topical hesperetin matrix film for back-of-the-eye delivery. Eur $\mathrm{J}$ Pharm Biopharm 92: 74-82.

26. Ananthula S, Parajuli P, Behery F, Ayoubi A, El Sayed K, et al. (2013) Abstract P3-03-11: Oxazine derivatives of $g$-and $D$-tocotrienols display potent anticancer effects in vivo. AACR.

27. Yallapu MM, Jaggi M, Chauhan SC (2012) Curcumin nanoformulations: a future nanomedicine for cancer. Drug Discov Today 17: 71-80.

28. Sanna V, Siddiqui IA, Sechi M, Mukhtar H (2013) Nanoformulation of natural products for prevention and therapy of prostate cancer. Cancer Lett 334: 142-151.

29. Ananthula S (2014) Bioavailability and bioequivalence issues associated with oral anticancer drugs and effect on drug market. J Bioequiv Availab 6: e56.

30. Hunter DJ, Manson JE, Colditz GA, Stampfer MJ, Rosner B, et al. (1993) A prospective study of the intake of vitamins $C, E$, and $A$ and the risk of breast cancer. NEJM 329: 234-240.
31. Adelli GR, Balguri SP, Bhagav P, Raman V, Majumdar S (2017) Diclofenac sodium ion exchange resin complex loaded melt cast films for sustained release ocular delivery. Drug Deliv 24: 370-379.

32. Chen J, Wang J, Kim TK, Tieu EW, Tang EK, et al. (2014) Novel vitamin $\mathrm{D}$ analogs as potential therapeutics: metabolism, toxicity profiling, and antiproliferative activity. Anticancer Res 34: 2153-2163.

33. Ananthula S, Parajuli P, Behery FA, Alayoubi AY, El Sayed KA, et al. (2014) Oxazine derivatives of ?-and d-tocotrienol display enhanced anticancer activity in vivo. Anticancer Res 34: 2715-2726.

34. Sylvester P, Valentino R (2007) Vitamin E-induced apoptosis in mouse mammary tumors. In: Valentino RG (ed.) New Cell Apoptosis Research Nova. Science Publisher, NY, USA pp: 53-68.

35. Ananthula S, Parajuli P, Behery FA, Alayoubi AY, Nazzal S, et al. (2014) $\delta$-tocotrienol oxazine derivative antagonizes mammary tumor cell compensatory response to $\mathrm{CoCl}_{2}$-induced hypoxia. BioMed Res Inter 2014: 1-13.

36. Ogasawara M, Matsubara T, Suzuki H (2001) Screening of natural compounds for inhibitory activity on colon cancer cell migration. Biol Pharm Bull 24: 720-723.

37. Ananthula S, Sinha A, El Gassim M, Batth S, Marshall GD, et al. (2010) Geminin overexpression-dependent recruitment and crosstalk with mesenchymal stem cells enhance aggressiveness in triple negative breast cancers. Oncotarget 7 : 20869-20889.

38. Hosain SB, Hill RA, Liu YY (2013) The role of sphingolipids in modulating pluripotency of stem cells. Trends in Stem Cell Proliferation and Cancer Research: Springer pp: 167-191.

39. Hosain SB, Khiste SK, Uddin MB, Vorubindi V, Ingram C, et al. (2016) Inhibition of glucosylceramide synthase eliminates the oncogenic function of p53 R273H mutant in the epithelial-mesenchymal transition and induced pluripotency of colon cancer cells. Oncotarget 7: 60575-60592.

40. Hosain SB, Liu YY (2015) Missense mutants of p53 tumor suppressor contributes to drug-resistance and epithelial-mesenchymal transition in colon cancer cells. Cancer Res 75: 5191-5191.

41. Hosain SB, Sultana S, Haque A (2011) Studies on antibacterial, cytotoxic and antioxidant properties of the seeds and leaves of Ficus racemosa. Int $J$ Pharmaceut Sci Res 2: 1040. 